\title{
An analysis of productive efficiency and innovation activity using DEA: An application to Spain's wood-based industry
}

\author{
Luis Diaz-Balteiro $^{\text {a,*}}{ }^{\text {, A. Casimiro Herruzo }}{ }^{\text {a }}$, Margarita Martinez ${ }^{\text {a }}$, \\ Jacinto González-Pachón ${ }^{\text {b,1 }}$
}

${ }^{\mathrm{a}}$ Technical University of Madrid, Department of Forest Economics and Management, Spain

${ }^{\mathrm{b}}$ Technical University of Madrid, Department of Artificial Intelligence, Spain

\begin{abstract}
This paper intends to analyze the relationship between productive efficiency and innovation activity in Spain's wood-based industry. The methodology includes two levels of analysis. First, a non-parametric technique (data envelopment analysis, DEA) is applied with several inputs and outputs associated to economic and financial data. In a second stage, a logistic regression model explores the relationship between the property of efficiency and innovation activity indicators. This approach is used to analyze a set of firms in the following sectors: lumber and wood products, pulp and paper and wood furniture. Results do not show the existence of significant links between firm's efficiency and innovation activities. This outcome is consistent with a low firm priority toward R\&D as a means to achieve competitiveness and an innovation strategy followed by many Spanish firms based on the acquisition of embodied technology available in international markets. In order to improve competitiveness in the long run, efforts should be made by Spanish wood-based firms to increase their production of in-house technologies.
\end{abstract}

\footnotetext{
* Corresponding author. Postal address: E.T.S. Ingenieros de Montes, Avenida Complutense s/n 28040 Madrid, Spain. Tel.: +3491336 42 96; fax: +34915439557.

E-mail address: luis.diaz.balteiro@upm.es (L. Diaz-Balteiro).

${ }^{1}$ Postal Address: Campus de Montegancedo s/n 28660 Boadilla del Monte, Madrid, Spain.
}

\section{Introduction}

The Spanish forest sector science and technology (S\&T) system has been transformed substantially in recent years. The funding, the organization and the institutional structure of research are substantially different today from those existing two decades ago. Drastic changes have also occurred in the amount of resources dedicated to research and development 
$(R \& D)$, as well as in the performance of the forest sector S\&T system.

Since the mid nineties, Spanish S\&T policy discourse has been leaning toward a more innovationcentered approach with an increasing emphasis on the development of technologies and the application of knowledge at the expense of the creation of knowledge. A resulting outcome has been the introduction of modifications in the program composition and budgetary distribution of the National R\&D Plan in order to enhance the promotion of innovation activity in the enterprise sector. In addition, new public-private partnerships initiatives have emerged in recent years (CICYT, 1999; Sanz-Menendez, 2003).

Budgetary increases along with institutional reforms have produced a positive impact on the scientific results of the forest sector S\&T system. In the period 1987-1999, the annual average rate of growth of the number of forestry items in the Science Citation Index (SCI) published by Spanish authors was $20.69 \%$, higher than in most developed countries (SCI search, 2004). The evolution of these items is shown in Table 1. However, the technological results of the Spanish forest sector S\&T system are still far behind its scientific achievements. During the period 1987-1999, Spain accounted for only $3.17 \%$ of the number of forestry and wood product patent applications submitted to the Spanish Patent Office (Oficina Española de Patentes y

Table 1

Forest Science items in SCI published by authors of Spain and patent applications submitted to the Spanish Patent Office (OEPM), 1987-1999

\begin{tabular}{lccc}
\hline Spanish SCI items & \multicolumn{2}{c}{ Patent applications } \\
\cline { 3 - 4 } & & Foreign & Spanish \\
\hline 1987 & 11 & 429 & 34 \\
1988 & 11 & 508 & 44 \\
1989 & 23 & 583 & 45 \\
1990 & 20 & 899 & 44 \\
1991 & 37 & 869 & 38 \\
1992 & 69 & 948 & 32 \\
1993 & 56 & 878 & 34 \\
1994 & 64 & 1013 & 33 \\
1995 & 94 & 1036 & 30 \\
1996 & 100 & 1113 & 32 \\
1997 & 121 & 1479 & 26 \\
1998 & 117 & 1759 & 18 \\
1999 & 127 & 1697 & 9 \\
\hline
\end{tabular}

Source: OEPM and SCI search (SCI, 2004).
Marcas, OEPM), lagging behind main European countries. Moreover, the proportion of Spanish patents has decreased throughout the same period (see Table 1).

The weak technological results of the Spanish forest sector S\&T system can be partially attributed to some unintended effects of R\&D funding and evaluation policies (Jiménez-Contreras et al., 2002; MCYT, 2003). Possibly, a more important factor is the persistent barriers to technology innovation characterizing the Spanish industrial sector. After more than two decades of Government innovations policies and technology transfer programs (see Sanz-Menendez, 2003), recent studies indicate a low entrepreneurial priority toward R\&D and other innovation activities as a means to achieve competitiveness (COTEC, 2004). This situation is particularly severe in the wood-based industry.

According to the National Institute of Statistics (INE), in 2001 the gross value added (GVA) of Spanish wood-based industry was 10,600 million $€$ amounting to more than $10.6 \%$ of Spain industrial sector GVA (INE, 2002). However, in terms of R\&D the relative importance of the wood-based industry within the industrial sector was lower than its economic proportion. In $2001 \mathrm{R} \& \mathrm{D}$ expenditures in the wood-based industry were only $1.3 \%$ of total industrial $R \& D$ expenditures in Spain. In the same year the number of researchers in the wood-based industry represented only $1.7 \%$ of the total number of researchers working in the industrial sector (INE, 2002). In 2002, the share of total expenditures in innovation activity in the wood-based industry, excluding $\mathrm{R} \& \mathrm{D}$, with respect to the whole industrial sector was $3.89 \%$. This figure is slightly more favorable than that of R\&D expenditures, but still relatively low (INE, 2002). Spanish wood-based industries R\&D intensity (percentage of R\&D expenditures on sales) during 1998-2001 was only 0.003\% (ESEE, 1998-2000). This is an extremely low figure when compared with other countries. For example, Globerman et al. (1999) indicate a R\&D intensity in the range of $0.4-1.0 \%$ for a variety of countries.

The Spanish wood-based sector is made of mostly small (less than 20 workers) and medium firms (between 20 and 50 workers). In 2003, a commercial survey taken at 5517 wood-based enterprises showed that $88.86 \%$ of the firms surveyed were small and medium enterprises with less than 50 workers. At least a minimum level of financial effort is required to set up R\&D and innovation activities and this thresh- 
old is often difficult to reach by many small firms. Furthermore, many small and medium size firms still consider the development of endogenous innovations as an additional and costly activity difficult to manage, and with long term intangible and doubtful results. These factors may explain the relative low budget appropriations to innovation activity that is typical for Spanish wood based firms. Following EUROSTAT, in this paper enterprises with innovation activity (propensity to innovate) covers all type of innovator, namely product innovators, process innovators, as well as enterprises with only ongoing and/or abandoned innovation activities to develop or introduce new or significantly improve products (goods or services) or implementing new processes, including R\&D activity (Eurostat, 2004).

The natural outcome of this situation is that the most frequent source of technological innovation (product and process) in the Spanish wood-based industry is the acquisition of embodied technology available in international markets (COTEC, 2004). Although this may have been a good strategy in the past, as a result of the new international environment, and in particular the recent enlargement of the EU, Spain wood-based industry may gradually lose its traditional competitive advantage brought about by lower labor costs within the European market. In 2001, the export-import ratio of Spanish wood-based industry was approximately $80 \%$. To maintain its current position in foreign and domestic markets, Spanish wood-based firms will have to look for new sources of competitiveness, such as the development of new industrial outputs and the reduction of production costs by implementing new and more efficient production processes. This may require an increase emphasis in the development of endogenous technologies.

Since the pioneering studies of Griliches (1980), Griliches and Mairesse (1984), the existence of a significant relationship between R\&D at the firm level and productivity was pointed out. Similar studies carried out at the industrial level using aggregate data have also confirmed the above relationship (Mansfield, 1984). Wood-based industry examples are scarce. For example, Bullard and Straka (1986) found a significant positive relationship between $R \& D$ expenditures and sales in five major US pulp and paper firms. In a more recent study Munn et al. (1998) analyzing 303 firms, over a wide range of forest products industries, also found a positive relationship between $R \& D$ expenditures and profitability in the long term, although R\&D expenditures were negatively related to growth in the short term. A positive relationship is usually assumed between other aspects of innovation activity and productivity in the forest sector (Das and Alavalapati, 2003).

In this study we investigated the relationship between R\&D and other innovation activities and production efficiency of Spanish wood-based industry, using a methodology which includes both a non-parametric technique, data envelopment analysis (DEA), and a logistic regression. Economic, financial, and innovation activity data variables are considered in our methodology.

The first data envelopment analysis (DEA) application to the forest sector was published by Rhodes (1986). However, the number of efficiency measurements in the forest literature based on non-parametric methods is still limited. These studies have focused on measuring efficiency in the private forest industry sector as well as on measuring forest management efficiency. Within the first group of studies, Yin (1998) applied DEA to analyze the efficiency of 44 paper firms in the United States considering seven inputs and one output (annual production). The same author (Yin, 1999), using the same procedure, also studied production efficiency and cost competitiveness of 70 pulp firms located in 10 countries of the Pacific Rim. This work was expanded in Yin (2000) to study technical and allocative efficiency measures for 102 mills in the world using DEA and stochastic frontier analysis (SFA). Fotiou (2000) estimated the efficiency of the Greek sawmills industry using a DEA model with 2 inputs (capital, workers) and 1 output (total product). More recently, Nyrud and Bergseng (2002) employed data envelopment analysis to measure productive efficiency in approximately 200 Norwegian sawmill firms. Hseu and Shang (2005) have applied DEA models in order to solve several distance functions used to construct Malmquist index in the pulp and paper industry. A recent overview of DEA and SFA application to timber production efficiency can be found in Carter and Siry (2003).

No previous applications of DEA to analyze innovation policies within forest products industry have been found. Logistic regression models have been applied to numerous fields including forestry. However, joint applications of DEA and logistic regres- 
sion are rare. The present paper is one of the first studies analyzing firms' innovation activity using both methodologies.

This article is organized as follows. We begin with a brief discussion of our methodology: DEA and logistic regression techniques. In the next section the data description is given. Then the empirical results are presented. The concluding section summarizes the main findings.

\section{Methodology}

\subsection{DEA technique}

Efficiency measurement studies of firms are carried out in order to assess firm's performance according to basic microeconomic principles, such as profit maximization (assumption considered in this study). Given that firms convert multiple inputs into multiple outputs, we need techniques to jointly analyze both inputs and outputs. Central to the firm's goal of profit maximizing is not only the minimal application of factors but also the correct allocation of input-factors in a way that an optimal output is achievable.

Three measures of efficiency can be applied: technical efficiency, scale efficiency and allocative efficiency. In this paper only technical and scale efficiency are considered, because measurement of allocative efficiency requires data on production costs not available in our database. Thus, we will analyze whether firms' inefficiencies are due to an excessive use of certain inputs (technical inefficiency), or to a suboptimal size (scale inefficiency).

The concept of technical efficiency can include an input orientation or an output orientation. In an inputoriented model a DMU [Decision Making Unit] will gain efficiency by maintaining its current levels of outputs and decreasing its inputs. In an output-oriented model a DMU will gain efficiency maintaining the inputs and increasing its outputs. DEA also provides information about scale efficiencies in production. Scale inefficiencies emerge when technology provides increasing returns to scale or decreasing return to scale.

Techniques developed to measure efficiency require the estimation of a production frontier to which firm's performance may be evaluated. Two set of techniques, parametric and non-parametric, are avail- able for empirical computation of stochastic or deterministic production frontiers. Parametric techniques specify a functional form for the production frontier using statistical techniques or a mathematical programming approach. Non-parametric techniques do not specify the functional form of the frontier. Instead these techniques establish a set of segments linking efficient units (firms) which is used to compare the rest of the units. This is the foundation of data envelopment analysis (DEA), the main non-parametric technique which uses linear programming to measure the relative efficiency of firms. Compared to regression or stochastic frontier analysis methods, DEA shows several advantages. First, DEA allows handling multiple inputs and outputs (with different units) in a noncomplex way. Second, DEA does not require any initial assumption about a specific functional form linking inputs and outputs. In contrast, DEA results may be affected by the well known limitations of this methodology, such as the influence of external data, the deterministic environment and the sensitiveness to measurement error.

In this study, we have chosen DEA for its simplicity to agglomerate different inputs and outputs and in order to avoid possible mistakes caused by erroneous specifications of the functional form. This is particularly relevant in our example that focuses on three sectors (lumber and wood products, pulp and paper, and wood furniture) in which empirical studies providing estimations of production frontiers functional forms are not available. In this study it is assumed that the DMUs fulfill the three necessary conditions for homogeneity (Haas and Murphy, 2003): the DMUs are engaged in the same process; the same measures of efficiency are applied to all DMUs; and all DMUs are operating under the same conditions.

Since DEA was introduced by Charner, Cooper and Rhodes (Charnes et al., 1978) several analytical models have been developed depending on the assumptions underlying the approach. For instance, the orientation of the analysis toward inputs or outputs, the existence of constant or variable (increasing or decreasing) returns to scale and the possibility of controlling inputs. Given the diversity of units characterizing our example, we first applied the $C C R$ model proposed in Charnes et al. (1978). This model assumes constant returns to scale and it is input-oriented. Following Cooper et al. (2000), we 
begin by the commonly used measure of efficiency (output/input ratio) and we try to find out the corresponding weights by using linear programming in order to maximize the ratio. To determine the efficiency of $n$ units (wood-based firms) $n$ linear programming problems must be solved to obtain the value of the weights $\left(v_{i}\right)$ associated with inputs $\left(x_{i}\right)$ as well as the value of weights $\left(u_{r}\right)$ associated with outputs $\left(y_{r}\right)$. Assuming $m$ inputs and $s$ outputs and transforming the fractional programming model into a lineal programming model, the CCR model can be formulated as follows (Cooper et al., 2000):

$$
\begin{aligned}
\operatorname{Max} \theta= & u_{1} y_{1,0}+\ldots+u_{s} y_{s, 0} \\
\text { subject to : } & v_{1} x_{1,0}+\ldots+v_{m} x_{m, 0}=1 \\
& u_{1} y_{1, j}+\ldots+u_{s} y_{s, j}-v_{1} x_{1, j}-\ldots-v_{m} x_{m, j} \leq 0 \quad(j=1 \ldots n) \\
& v_{1}, v_{2}, \ldots v_{m} \geq 0 \\
& u_{1}, u_{2}, \ldots u_{s} \geq 0 .
\end{aligned}
$$

Due to the lack of information concerning the form of the production frontier, an extension of the CCR model described in (1), the BCC (Banker-Charnes-Cooper) model was also used (Banker et al., 1984). This model incorporates the property of variable returns to scale. Oriented toward minimizing inputs, the $\mathrm{BCC}$ model has the following form:

$$
\begin{aligned}
\operatorname{Max} \theta= & u_{1} y_{1,0}+\ldots+u_{s} y_{s, 0}-u_{0} \\
\text { subject to : } & v_{1} x_{1,0}+\ldots+v_{m} x_{m, 0}=1 \\
& u_{1} y_{1, j}+\ldots+u_{s} y_{s, j}-v_{1} x_{1, j}-\ldots-v_{m} x_{m, j}-u_{0} \leq 0 \quad(j=1 \ldots n) \\
& v_{1}, v_{2}, \ldots v_{m} 0 \\
& u_{1}, u_{2}, \ldots u_{s} 0 .
\end{aligned}
$$

Where $u_{0}$ is the variable allowing identification of the nature of the returns to scale. This model does not predetermine if the value of this variable is positive (increasing returns) or is negative (decreasing returns).

As available data doesn't include accurate measures about the outputs' prices, we have chosen a DEA input-oriented model. This means that one unit would be technically efficient if it produces the maximum amount of outputs with the least possible inputs. In this study, both the CCR model and the BBC model are applied. The assumption of constant return to scale adopted in the CCR model is a convenient hypothesis only when all firms are operating at an optimum scale. However, the BCC model avoids the scale biased problems when measuring technical efficiency. In addition, the use of both models allows the measurement of scale efficiency: for each unit scale efficiency is the ratio between $\mathrm{CCR}$ and BCC efficiencies. Identical CCR and BCC results would imply that the unit considered is operating at an optimal scale.
One of the main problems with DEA techniques is the correct selection of inputs and outputs. Other difficulties are the homogeneity assumptions and the flexibility of restrictions regarding the weights (Dyson et al., 2001). Following these authors, the greater the number of factors included in the analysis, the lower the level of discrimination. To avoid this problem several approximations can be found in the literature. Authors like Sun (2002) compute correlations between inputs and outputs and examine input-output relations through multiple linear regression models. Additional statistical techniques can also be used to justify the selection of inputs and outputs. For instance, Zhu (1998), Nasierowski and Arcelus (2003) and Serrano Cinca and Mar Molinero (2004) have employed principal components analysis to reduce the number of variables used. Other authors have used cluster analysis (Serrano Cinca and Mar Molinero, 2004) or alternative methodologies based on multivariate analysis (Jenkins and Anderson, 2003). In this study we follow the method proposed by Pastor et al. (2002) based on analyzing 
the behavior of the model when an additional variable is included. The decision whether to include an additional variable (input or output) depends on its impact on either the average efficiency of the decision making units (DMUs) or on the number of efficient DMUs. Finally, reductions in the number of inputs and outputs can be made as long that the results of the model are not affected.

In order to determine the influence of additional variables on DEA technical efficiency results, several statistical tools, parametric and non-parametric have been proposed. Regression analysis and analysis of variance are frequently applied to investigate the relationship between the efficiency scores and other variables. For example, Iráizoz et al. (2003) examine correlations between efficiency and several variables (size, factorial returns, economic performance) of 46 horticultural farms. Fotiou (2000) analyzes the relationships between technical efficiency indexes and two logistical operations in Greek sawmills using single factor ANOVA. Alternatively, censored regression analysis (Tobit regression models) has been used by Nyrud and Bergseng (2002) to evaluate the efficiency of near 200 mills. Among the non-parametrical methods analyzing the results of DEA models, Nyrud and Bergseng (2002) have employed the Kruskal-Wallis $k$-sample test. A good review of these applications is provided in Grosskopf (1996).

\subsection{Logistic regression model}

In this section a logistic regression analysis is developed in order to set up links between DMUs efficiency and several innovation activity variables. Our objective is to model the relationship between a binary response variable (one $=$ efficiency; zero $=$ no efficiency) and a selected explanatory variable. Specifically, an univariate logistic regression uses the binomial distribution to model the variation in a binary response (Agresti, 1996; Ryan, 1997).

The probability to be efficient may be expressed by a parameter $p$ in a binomial distribution. If we denote by $Z$ the efficiency response variable and by $x_{i}$ the selected explanatory variable, the relationship between $Z$ and $p$ is the following:

$p=P\left[Z=1 \mid x_{i}\right]$.
Thus the probability to be efficient, $p$, may be modeled as the follows:

$\ln \left(\frac{p}{1-p}\right)=\beta_{0}+\beta_{1} x_{1}$

This model is fit using maximum likelihood. The Goodness-of-Fit is analyzed from the percentage of deviance the model accounts for. This value is similar to the $R$-square statistic. Thus, if the $p$-value is less than 0.05 , there is a statistically significant relationship between efficiency (variable $Z$ ) and $x_{i}$.

\section{Data}

The data used in this study comes from two different sources. Firstly, the Survey of Business Strategies (Encuesta sobre Estrategias Empresariales) is an annual survey carried out by a Spanish public organization (SEPI Foundation) over a large sample of Spanish industrial firms. During the period 1998-2001 this survey collected annual data from a set of woodbased firms ranging from 143 firms in 1998 to 171 firms in 2001. For a large set of these firms this information was matched with additional economic and financial data (number of workers, shareholder's funds, loans, sales, and profit before taxes) from a commercial database. In order to homogenize the information, only those firms for which a complete set of data was available during the four years period were considered in the study. Therefore, firms that entered or left the sample surveyed during the period were not included reducing to 61 the number of firms studied.

Five input and five output variables were selected. Table 2 shows the information concerning these variables for the total of wood-based firms and for each wood-based firm group: lumber and wood products, pulp and paper and wood furniture. In each case and for each variable, mean values, standard deviation, and maximum and minimum values are presented. In the input side, one variable relates to labor factor (total number of employees, $x_{1}$ ) and two variables refer to the liabilities' structure of the firms (shareholder's funds, $x_{2}$, and loans, $x_{3}$ ). The other two input variables have to do with the firm's innovation activity: R\&D expenditures $\left(x_{4}\right)$ and R\&D partnerships $\left(x_{5}\right)$. The later is a qualitative variable which adopt an integer value be- 
Table 2

Main features of the variables included in the DEA model $\left(x_{1}, x_{2}, x_{3}, y_{1}, y_{2}\right)$ and in the logistic regression model $\left(x_{4}, x_{5}, y_{3}, y_{4}, y_{5}\right)$

\begin{tabular}{|c|c|c|c|c|c|c|c|c|c|c|}
\hline & $\begin{array}{l}x_{1} \\
\text { employees }\end{array}$ & $\begin{array}{l}\mathrm{x}_{2} \\
\text { shareholder's } \\
\text { funds } \\
(\times 1000 €)\end{array}$ & $\begin{array}{l}x_{3} \\
\text { loans } \\
(\times 1000 €)\end{array}$ & $\begin{array}{l}x_{4} \\
\text { R\&D } \\
\text { expenditures } \\
(\times 1000 €)\end{array}$ & $\begin{array}{l}x_{5}{ }^{*} \\
\text { R\&D } \\
\text { partnerships }\end{array}$ & $\begin{array}{l}y_{1} \\
\text { sales } \\
(\times 1000 €)\end{array}$ & $\begin{array}{l}y_{2} \\
\text { profits } \\
\text { before taxes } \\
(\times 1000 €)\end{array}$ & $\begin{array}{l}y_{3} \\
\text { patents }\end{array}$ & $\begin{array}{l}y_{4} \\
\text { product } \\
\text { innovations }\end{array}$ & $\begin{array}{l}y_{5} * * \\
\text { process } \\
\text { innovations }\end{array}$ \\
\hline \multicolumn{11}{|l|}{ Mean } \\
\hline All DMUs & 211 & $15,275.20$ & $17,972.19$ & 109.81 & 1.08 & $37,029.92$ & 2332.05 & 1.68 & 2.39 & 0.74 \\
\hline $\begin{array}{l}\text { Lumber } \\
\text { and wood } \\
\text { products }\end{array}$ & 152 & 3490.87 & 7531.59 & 30.83 & 0.72 & $15,075.33$ & 573.09 & 0.11 & 0.50 & 1.03 \\
\hline $\begin{array}{l}\text { Pulp and } \\
\text { paper } \\
\text { industry }\end{array}$ & 294 & $27,242.29$ & $30,760.28$ & 159.68 & 1.27 & $62,334.94$ & 3989.29 & 0.43 & 0.73 & 0.74 \\
\hline $\begin{array}{l}\text { Wood } \\
\text { furniture }\end{array}$ & 129 & 4797.52 & 5933.54 & 77.84 & 0.98 & $13,714.53$ & 930.77 & 3.86 & 5.20 & 0.63 \\
\hline \multicolumn{11}{|c|}{ Standard deviation } \\
\hline All DMUs & 354 & $48,373.64$ & $48,104.19$ & 245.85 & 1.35 & $87,394.95$ & 7481.65 & 10.47 & 11.11 & 0.81 \\
\hline $\begin{array}{l}\text { Lumber } \\
\text { and wood } \\
\text { products }\end{array}$ & 183 & 4924.55 & 9920.91 & 60.41 & 0.88 & $18,716.08$ & 982.97 & 0.52 & 1.18 & 0.77 \\
\hline $\begin{array}{l}\text { Pulp and } \\
\text { paper } \\
\text { industry }\end{array}$ & 462 & $67,412.03$ & $66,509.26$ & 306.23 & 1.57 & $119,039.37$ & $10,349.76$ & 3.14 & 2.57 & 0.82 \\
\hline $\begin{array}{l}\text { Wood } \\
\text { furniture }\end{array}$ & 186 & $12,160.84$ & $12,373.36$ & 186.58 & 1.16 & $28,227.34$ & 2649.87 & 16.51 & 17.52 & 0.78 \\
\hline \multicolumn{11}{|l|}{ Minimum } \\
\hline All DMUs & 15 & -1009.75 & 13.01 & 0.00 & 0.00 & 3.87 & $-10,073.74$ & 0.00 & 0.00 & 0.00 \\
\hline $\begin{array}{l}\text { Lumber } \\
\text { and wood } \\
\text { products }\end{array}$ & 15 & 105.10 & 201.00 & 0.00 & 0.00 & 1656.92 & -208.86 & 0.00 & 0.00 & 0.00 \\
\hline $\begin{array}{l}\text { Pulp and } \\
\text { paper } \\
\text { industry }\end{array}$ & 17 & 49.12 & 318.98 & 0.00 & 0.00 & 2246.56 & $-10,073.74$ & 0.00 & 0.00 & 0.00 \\
\hline $\begin{array}{l}\text { Wood } \\
\text { furniture }\end{array}$ & 15 & -1009.75 & 13.01 & 0.00 & 0.00 & 3.87 & -1603.04 & 0.00 & 0.00 & 0.00 \\
\hline \multicolumn{11}{|l|}{ Maximum } \\
\hline All DMUs & 2499 & $469,442.57$ & $382,300.93$ & 1772.99 & 5.00 & $673,190.03$ & $84,622.54$ & 150.00 & 125.00 & 2.00 \\
\hline $\begin{array}{l}\text { Lumber } \\
\text { and wood } \\
\text { products }\end{array}$ & 600 & $18,872.83$ & $33,618.82$ & 213.12 & 3.00 & $58,610.50$ & 3955.98 & 3.00 & 5.00 & 2.00 \\
\hline $\begin{array}{l}\text { Pulp and } \\
\text { paper } \\
\text { industry }\end{array}$ & 2499 & $469,442.57$ & $382,300.93$ & 1772.99 & 5.00 & $673,190.03$ & $84,622.54$ & 33.00 & 20.00 & 2.00 \\
\hline $\begin{array}{l}\text { Wood } \\
\text { furniture }\end{array}$ & 851 & $72,841.96$ & $88,759.09$ & 1067.94 & 4.00 & $167,432.04$ & $17,620.33$ & 150.00 & 125.00 & 2.00 \\
\hline
\end{tabular}

* Variable $x_{5}$ indicates mean values of observations adopting values between 0 and 2 .

** Variable $y_{5}$ indicates mean values of observations adopting values between 0 and 5 .

tween 0 and 5 depending on the number of R\&D partnerships with public research organizations and/or with other firms. A 0 value means that R\&D partner- ships are non-existent. Ordinal variables are introduced in the model one by one, to see what effect each has on the results. Unfortunately, the Survey of Business Strat- 
egies used in this study does not include any resource variable, such as, timber, pulp, energy consumption and others.

Five output variables were considered. Two related to the firm's objectives (sales, $y_{1}$ ) and profits before taxes, $\left(y_{2}\right)$ and three related to the firm's R\&D and other innovation activities: number of patents $\left(y_{3}\right)$, number of product innovations $\left(y_{4}\right)$, and process innovations, $\left(y_{5}\right)$. Product innovations involve the introduction of new and significantly improved goods and/ or services with respect to their fundamental characteristics, technical specifications, incorporated software or other immaterial components, intended uses, or user friendliness (Eurostat, 2004). Process innovation was treated as a qualitative variable taking value 1 if the firm adopted one of the two types of process innovation considered (the introduction of new and significantly improved production technologies or new and significantly improved organizational and managerial changes); value 2 if the firm adopted both types of process innovation, and value 0 if the firm did not adopt any process innovation.

Our base case DEA model includes 3 inputs, number of employees $\left(x_{1}\right)$, shareholder's funds $\left(x_{2}\right)$, loans $\left(x_{3}\right)$; and 2 outputs, sales $\left(y_{1}\right)$ and profit before taxes $\left(y_{2}\right)$. In the logistic regression model, 2 inputs $\left(x_{4}, x_{5}\right)$ and 3 outputs were chosen $\left(y_{3}, y_{4}, y_{5}\right)$.

Finally, to deal with the degrees of freedom problem in our DEA application, in any of the 4 years studied (1998 to 2001), the input-output values of each firm were regarded as a single DMU. Hence, each firm was considered again as a different DMU for each of the 4 successive years of the period. The resulting analysis was $244(=61 \times 4)$ DMUs. This approach has been previously used by Charnes et al. (1985) and Sun (2002). With this procedure the number of DMUs is greater than twice the product of the number of inputs and the number of outputs. This guideline is suggested in many DEA studies (e.g., Dyson et al., 2001).

\section{Results}

Our base case DEA model shows a high global efficiency value and a high level of discrimination among DMUs. It was not possible to obtain another model with these characteristics by incorporating any of the innovation activity variables. Firstly, the increase in average efficiency shown by the CCR model was non-significant. Secondly, when applying the BCC model, a much larger number of DMUs becomes efficient indicating that the model did not correctly discriminate among efficient and inefficient units. For instance, when introducing R\&D expenditures $\left(x_{4}\right)$ or $\mathrm{R} \& \mathrm{D}$ partnerships $\left(x_{5}\right)$, the number of efficient units in the BCC model rose from $10.66 \%$ of DMUs in the base case to $57-61 \%$.

Efficiency measurement results of our base case DEA model are shown in Table 3. Average technical efficiency is around $70 \%$ regardless of the model used (CCR or BCC). Scale efficiency reaches a higher value. When all the units are considered, the percentage of efficient firms ranges from $6.15 \%$ to $10.66 \%$ depending on whether the model employed is CCR or $\mathrm{BCC}$, respectively. In the case of the lumber and wood product industry, scale efficiency is higher than technical efficiency, this means that global inefficiencies are mainly attributed to inefficient operations or man-

Table 3

Results obtained with the base case DEA model

\begin{tabular}{|c|c|c|c|c|c|c|}
\hline & \multicolumn{2}{|c|}{ CCR model } & \multicolumn{2}{|c|}{ BCC model } & \multicolumn{2}{|c|}{ Scale efficiency } \\
\hline & $\begin{array}{l}\text { Efficient } \\
\text { DMUs }\end{array}$ & $\%$ total & $\begin{array}{l}\text { Efficient } \\
\text { DMUs }\end{array}$ & $\%$ total & $\begin{array}{l}\text { Efficient } \\
\text { DMUs }\end{array}$ & $\%$ total \\
\hline All DMUs & 15 & 6.15 & 26 & 10.66 & 18 & 7.38 \\
\hline Lumber and wood products & 3 & 8.33 & 3 & 8.33 & 4 & 11.11 \\
\hline Pulp and paper industry & 7 & 6.03 & 14 & 12.07 & 7 & 6.03 \\
\hline Wood furniture & 5 & 5.43 & 9 & 9.78 & 7 & 7.61 \\
\hline Average efficiency & & & & & & \\
\hline Standard deviation & & & & & & \\
\hline Minimum & & & & & & \\
\hline Maximum & & & & & & \\
\hline
\end{tabular}


agement. On the other hand, in most cases, paper and wood furniture industries could improve their efficiency by scaling up their activities.

Our DEA model results do not establish a significant relationship between the innovation activity variables and the level of technical and/or scale efficiency. Table 4 relate the set of efficient firms with firm's innovation activity variables. In Table 4 , except in the BCC model, efficient firms tend to be associated with no R\&D activities. With the CCR model average efficiency values are slightly higher in firms with no R\&D expenditures and with no R\&D partnerships. However, differences are found among the three industrial sectors. In the pulp and paper industry, technical and scale efficiency tend to be associated with the existence of R\&D partnerships. The opposite situation is found in the lumber and wood product industry where efficient firms are found without R\&D expenditures and without R\&D partnerships. In Table 4 efficient DMUs tend to be associated with the inexistence of patents. However, DEA (and also logistic regression) results obtained with the variable patents must be look with caution because only 34 DMUs stated that they have developed patents. In addition, no positive relationship is found between product and process innovations with efficiency.

Two inputs (R\&D expenditures, $x_{4}$, and $R \& D$ partnerships, $x_{5}$ ) and three outputs (number of patents, $y_{3}$, product innovations, $y_{4}$, and process innovations, $y_{5}$ ) were examined as possible explanatory (independent) variable in each of the univariate logistic regression models. A binary variable $Z$ de-

Table 4

Efficient firms and average efficiency values associated with innovation activity

\begin{tabular}{|c|c|c|c|c|c|c|c|c|c|c|}
\hline & & \multicolumn{3}{|c|}{$\begin{array}{l}\text { DMUs without } \\
\text { R\&D expenditures }\end{array}$} & \multicolumn{2}{|c|}{$\begin{array}{l}\text { DMUs with } \\
\text { R\&D expenditures }\end{array}$} & \multicolumn{2}{|c|}{$\begin{array}{l}\text { DMUs without } \\
\text { R\&D partnerships }\end{array}$} & \multicolumn{2}{|c|}{$\begin{array}{l}\text { DMUs with } \\
\text { R\&D partnerships }\end{array}$} \\
\hline \multicolumn{11}{|l|}{ Efficient DMUs } \\
\hline \multirow{4}{*}{$\begin{array}{l}\text { Technical efficiency } \\
\text { (CCR model) }\end{array}$} & All DMUs & 12 & & & 3 & & 10 & & 5 & \\
\hline & Lumber and wood products & 3 & & & 0 & & 3 & & 0 & \\
\hline & Pulp and paper industry & 5 & & & 2 & & 3 & & 4 & \\
\hline & Wood furniture & 4 & & & 1 & & 4 & & 1 & \\
\hline \multirow{4}{*}{$\begin{array}{l}\text { Technical efficiency } \\
\text { (BCC model) }\end{array}$} & All DMUs & 15 & & & 11 & & 13 & & 13 & \\
\hline & Lumber and wood products & 3 & & & 0 & & 3 & & 0 & \\
\hline & Pulp and paper industry & 7 & & & 7 & & 5 & & 9 & \\
\hline & Wood furniture & 5 & & & 4 & & 5 & & 4 & \\
\hline \multirow[t]{5}{*}{ Scale efficiency } & All DMUs & 13 & & & 5 & & 11 & & 7 & \\
\hline & Lumber and wood products & 4 & & & 0 & & 4 & & 0 & \\
\hline & Pulp and paper industry & 5 & & & 2 & & 3 & & 4 & \\
\hline & Wood furniture & 4 & & & 3 & & 4 & & 3 & \\
\hline & & $\begin{array}{l}\text { DMUs } \\
\text { without } \\
\text { patents }\end{array}$ & $\begin{array}{l}\text { DMUs } \\
\text { with } \\
\text { patents }\end{array}$ & & $\begin{array}{l}\text { MUs } \\
\text { hout products } \\
\text { ovations }\end{array}$ & $\begin{array}{l}\text { DML } \\
\text { with } \\
\text { inno }\end{array}$ & $\begin{array}{l}\text { s } \\
\text { oroducts } \\
\text { ations }\end{array}$ & $\begin{array}{l}\text { DMUs } \\
\text { without proces } \\
\text { innovations }\end{array}$ & ess & $\begin{array}{l}\text { DMUs } \\
\text { with process } \\
\text { innovations } \\
\end{array}$ \\
\hline \multicolumn{11}{|l|}{ Efficient DMUs } \\
\hline \multirow{4}{*}{$\begin{array}{l}\text { Technical efficiency } \\
\text { (CCR model) }\end{array}$} & All DMUs & 15 & 0 & 11 & & 4 & & 10 & & 5 \\
\hline & Lumber and wood products & 3 & 0 & 3 & & 0 & & 1 & & 2 \\
\hline & Pulp and paper industry & 7 & 0 & 5 & & 2 & & 6 & & 1 \\
\hline & Wood furniture & 5 & 0 & 3 & & 2 & & 3 & & 2 \\
\hline \multirow{4}{*}{$\begin{array}{l}\text { Technical efficiency } \\
\text { (BCC Model) }\end{array}$} & All DMUs & 26 & 0 & 15 & & 11 & & 16 & & 10 \\
\hline & Lumber and wood products & 3 & 0 & 3 & & 0 & & 1 & & 2 \\
\hline & Pulp and paper industry & 14 & 0 & 9 & & 5 & & 9 & & 5 \\
\hline & Wood furniture & 9 & 0 & 3 & & 6 & & 6 & & 3 \\
\hline \multirow[t]{4}{*}{ Scale efficiency } & All DMUs & 17 & 1 & 12 & & 6 & & 11 & & 7 \\
\hline & Lumber and wood products & 4 & 0 & 4 & & 0 & & 1 & & 3 \\
\hline & Pulp and paper industry & 7 & 0 & 5 & & 2 & & 6 & & 1 \\
\hline & Wood furniture & 6 & 1 & 3 & & 4 & & 4 & & 3 \\
\hline
\end{tabular}


Table 5

Results obtained with the logistic regression: $p$-value from the analysis of deviance

\begin{tabular}{llll}
\hline & $\begin{array}{l}\text { Efficiency score } \\
\text { from CCR model }\end{array}$ & $\begin{array}{l}\text { Efficiency score } \\
\text { from BCC model }\end{array}$ \\
\cline { 2 - 2 } & $p$-value & & $p$-value \\
\hline$x_{4}$ (R\&D expenditures) & 0.0018 & 0.5143 \\
$x_{5}$ (R\&D partnerships) & 0.1947 & 0.4513 \\
$y_{3}$ (patents) & 0.3137 & 0.0477 \\
$y_{4}$ (product innovations) & 0.7949 & 0.7412 \\
$y_{5}$ (process innovations) & 0.1569 & 0.1636 \\
\hline
\end{tabular}

fined as $Z=1$ for efficient firms and $Z=0$ for no efficient firms describes the dependent variable in all models. We focus on a Goodness-of-Fit statistic based on the deviance explained by the model. The results of the logistic regression models recorded as $p$-values from the analysis of deviance are shown in Table 5.

When we consider the efficiency scores from the BCC model, a non-significant relationship is found between the dependent variable $(Z)$ and the independent variables $x_{4}, x_{5}, y_{4}$ and $y_{5}$ ( $p$-values less than 0.05 in Table 5). On the other hand, there is a relationship between $Z$ and the number of patents $\left(y_{3}\right)$. When looking at the value of the parameter $\beta_{1}$ included in Eq. (3) a negative sign is found. Therefore, it could be argued that the property of efficiency in the DMUs considered $(Z)$ is inversely correlated with the existence of patents $\left(y_{3}\right)$. However, as we are using a $95 \%$ significance level, we observe that the associated $p$-value lies very near the limit of the reject region $(p=0.0477 \approx 0.05)$. Finally, a similar interpretation can be obtained from the efficiency scores of the CCR model. In this case there is only a significant relationship between the efficiency and R\&D expenditures $\left(x_{4}\right)$. The sign of this relationship is negative, which suggests an inverse relation between $R \& D$ expenditures and the property of efficiency.

\section{Discussion and conclusion}

Results obtained in our base case DEA model (without innovation activity variables) show average technical inefficiency in the range of $26-30 \%$, Hence firms operating at the correct scale could save up to $26-30 \%$ of their inputs to produce the same amount of output. These figures indicate much lower levels of technical efficiency than those found in similar woodbased industry studies carried out in other countries (Yin, 1998, 1999; Nyrud and Bergseng, 2002). Scale inefficiency results indicate a lower figure than technical inefficiency (approximately 6\%).

The lack of significant links between firm's efficiency and firm's innovation activity was also confirmed by both DEA and our logistic regression analysis. It should be noted that these results could be biased due to data structure, and the well known limitations of DEA methodology. However, the above outcome seems consistent with the low entrepreneurial priority toward innovation activity as a means to achieve competitiveness detected in many Spanish firms (COTEC, 2004).

The impact of firm's R\&D and other innovation activities on the level of efficiency depends heavily on both the amount and the composition of innovation expenditures. Our results indicate that most Spanish wood-based firms may have not reached the minimum level of financial effort required to set up effective R\&D and innovation activities contributing of to the creation of effective endogenous technologies. On the contrary, as it has been pointed out (COTEC, 2004), the innovation strategy followed by many Spanish firms has been essentially focused on the acquisition of embodied technology available in international markets instead of on the development of in-house technology. Therefore, the conversion of public and private $R \& D$ investments into technological results appears to be the immediate challenge for the Spanish forest sector S\&T innovation system.

\section{Acknowledgements}

This research was supported by the Spanish 'Ministerio de Ciencia y Tecnología (MCYT)' under project BEC2001-2353 and by the 'Fundación BBVA' under project Timber Sustainable Production: Economic and Environmental Aspects. The support of our colleagues of the Spanish Multi-Criteria Network is appreciated. We would like to thank Professor Carlos Romero for his comments that have greatly improved the accuracy of the paper. Valuables comments of three referees are also highly appreciated. 
Finally, we would like to thank Professor Joana Pierce for editing the English.

\section{References}

Agresti, A., 1996. An Introduction to Categorical Data Analysis. John Wiley, New York.

Banker, R.D., Charnes, A., Cooper, W.W., 1984. Some models for estimating technical and scale inefficiencies in data envelopment analysis. Management Science 30, 1078-1092.

Bullard, S.H., Straka, T.J., 1986. Role of company sales in funding research and development by major U.S. paper companies. Forest Science 32 (4), 936-943.

Carter, D.R., Siry, J.P., 2003. Timber production efficiency analysis. In: Sills, E.O., Abt, K.L. (Eds.), Forests in a Market Economy. Kluwer Academic Publishers, Dordrecht, The Netherlands, pp. 97-115.

Charnes, A., Cooper, W.W., Rhodes, E., 1978. Measuring the efficiency of decision making units. European Journal of Forest Research 2, 429-444.

Charnes, A., Clark, C.T., Cooper, W.W., Golany, B., 1985. A development study of data envelopment analysis in measuring the efficiency of maintenance units in the US air forces. Annals of Operational Research 2, 95-112.

CICYT, 1999. Plan Nacional de Investigación Científica Desarrollo e Innovación Tecnológica 2000-2003. Volumen I y Volumen 2, Comisión Interministerial de Ciencia y Tecnología, Madrid.

Cooper, W.W., Seiford, L.M., Tone, K., 2000. Data Envelopment Analysis. Kluwer Academic Publishers, Dordrecht, The Netherlands.

COTEC, 2004. Libro verde. Situación en 2003 del Sistema Español de Innovación. http://www.cotec.es/.

Das, G.G., Alavalapati, J.R.R., 2003. Trade-mediated biotechnology transfer and its effective absorption: an application to the U.S. forest sector. Technological Forecasting \& Social Change 70, $545-562$.

Dyson, R.G., Allen, R., Camanho, A.S., Podinovski, V.V., Sarrico, C.S., Shale, E.A., 2001. Pitfalls and protocols in DEA. European Journal of Forest Research 132, 245-259.

ESEE, Encuesta sobre Estrategias Empresariales, 1998-2000. Fundación SEPI, Madrid.

Eurostat, 2004. Third community innovation survey. Eurostat Metadata in Sdds: Summary Methodology. Last Update September 2004.

Fotiou, S., 2000. Efficiency measurement and logistics — an application of DEA in Greek sawmills. In: Sjöstrom, K. (Ed.), Logistics in the Forest Sector. Proceedings of the First World Symposium on Logistics in Forest Sector, Timber Logistics Club, Helsinki, pp. 189-204.

Globerman, S., Nakamura, M., Ruckman, K., Vertinsky, I., Williamson, T., 1999. Technological progress and competitiveness in the Canadian forest products industry. Canadian Forest Service. Natural Resources Canada, Ottawa.
Griliches, Z., 1980. Returns to research and development expenditures in the private sector. In: Kendrick, J., Vaccara, B. (Eds.), New Developments in Productivity Measurement and Analysis, Conference on Research in Income and Wealth, vol. 44. Chicago University Press for the National Bureau of Economic Research, Chicago, pp. 419-461.

Griliches, Z., Mairesse, J., 1984. Productivity and R\&D at the firm level. In: Griliches, Z. (Ed.), R\&D, Patents and Productivity. Chicago University Press for the National Bureau of Economic Research, Chicago, pp. 339-374.

Grosskopf, S., 1996. Statistical inference and nonparametric efficiency: a selective survey. Journal of Productivity Analysis 7, $161-166$.

Haas, D.A., Murphy, F.H., 2003. Compensating for nonhomogeneity in decision-making units in data envelopment analysis. European Journal of Operational Research $144,530-544$

Hseu, J.S., Shang, J.K., 2005. Productivity changes of pulp and paper industry in OECD countries, 1991-2000: a non-parametric Malmquist approach. Forest Policy and Economics 7, $411-422$.

INE, 2002. Estadisticas Sobre las Actividades en Investigación Científica y Desarrollo Tecnológico (I+D), 2001. Madrid.

Iráizoz, B., Rapún, M., Zabaleta, I., 2003. Assessing the technical efficiency of horticultural production in Navarra, Spain. Agricultural Systems 78, 387-403.

Jenkins, L., Anderson, M., 2003. A multivariate statistical approach to reducing the number of variables in data envelopment analysis. European Journal of Operational Research 147, $51-61$.

Jiménez-Contreras, E., de Moya Anegón, F., Delgado López-Cózar, E., 2002. The evolution of research activity in Spain. The impact of the National Commission for the Evaluation of Research Activity (CNEAI). Research Policy 32, 123-142.

Mansfield, E., 1984. R\&D and innovation: some empirical findings. In: Griliches, Z. (Ed.), R\&D, Patents and Productivity. Chicago University Press for the National Bureau of Economic Research, Chicago, pp. 127-154.

MCYT, 2003. El Plan Nacional de I+D+I (2000-2003): Informe Sobre su Evaluación. http://www.mcyt.es/planidi/.

Munn, I.A., Hodges, D.G., Truitt, T., 1998. Determinants of Research and Development Expenditures in the Forest Product Industry. Forest and Wildlife Research Center, Mississippi State University, pp. 83-87.

Nasierowski, W., Arcelus, F.J., 2003. On the efficiency of national innovation systems. Socio-Economic Planning Sciences 37, $215-234$.

Nyrud, A.Q., Bergseng, S., 2002. Production efficiency and size in Norwegian sawmilling. Scandinavian Journal of Forest Research 17, 566-575.

Pastor, J., Ruiz, J.L., Sirvent, I., 2002. A statistical test for nested radial DEA models. Operations Research 50 (4), $728-735$.

Rhodes, E., 1986. An explanatory analysis of variations in performance among U.S. national parks. In: Silkman, R. (Ed.), Measuring Efficiency: An Assessment of Data Envelopment Analysis, pp. 47-71. 
Ryan, T.P., 1997. Modern Regression Methods. John Wiley, New York.

Sanz-Menendez, L., 2003. Public/Private Partnerships and Innovation Policy: the Spanish Experience, Unidad de Políticas Comparadas (CSIC), Working Paper 03-01, Madrid.

SCI, 2004. Science Citation Index Expanded. ISI Web of Knowledgement. http://go5.isiknowledge.com/portal.cgi?DestApp= WOS\&Func $=$ Frame .

Serrano Cinca, C., Mar Molinero, C., 2004. Selecting DEA specifications and ranking units via PCA. Journal of the Operational Research Society 55, 521-528.

Sun, S., 2002. Measuring the relative efficiency of police precincts using data envelopment analysis. Socio-Economic Planning Sciences 36, 51-71.
Yin, R., 1998. DEA - a new methodology for evaluating the performance of forest products producers. Forest Products Journal 48 (1), 29-34.

Yin, R., 1999. Production efficiency and cost competitiveness of pulp producers in the Pacific Rim. Forest Products Journal 49 (7/8), 43-49.

Yin, R., 2000. Alternative measurements of productive efficiency in the global bleached softwood pulp sector. Forest Science 46 (4), $558-569$.

Zhu, J., 1998. Data envelopment analysis vs. principal component analysis: an illustrative study of economic performance of Chinese cities. European Journal of Operational Research 111, $50-61$. 